https://doi.org/10.5800/GT-2017-8-3-0287

\title{
INTRA-OCEANIC ARCS OF THE PALEO-ASIAN OCEAN
}

\author{
I. Safonova1, 2, A. Kotlyarov¹, S. Krivonogov, 2 \\ ${ }^{1}$ V.S. Sobolev Institute of Geology and Mineralogy, Siberian Branch RAS, Novosibirsk, Russia \\ ${ }^{2}$ Novosibirsk State University, Novosibirsk, Russia
}

For citation: Safonova I., Kotlyarov A., Krivonogov S., 2017. Intra-oceanic arcs of the Paleo-Asian ocean. Geodynamics \& Tectonophysics 8 (3), 547-550. doi:10.5800/GT-2017-8-3-0287.

Intra-oceanic arcs (IOAs) form at Pacific-type convergent margins, in the upper "stable" plate, when the subducting plate submerges to the depths of melting, i.e., to ca. $50-100 \mathrm{~km}$. A typical IOA system, such as Mariana-Bonin and the Philippines Sea, consists of subduction zone, fore-arc region with accretionary prism, frontal or active arc, marginal basin with spreading center, and, in some cases, one or more remnant arcs and inactive marginal basin. The IOAs are very important elements of Pacific-type convergent margins as they represent major sites of juvenile continental crust formation (e.g. [Clift et al., 2003; Stern, 2010; Maruyama et al., 2011]), but are also the most important sites of crust removal by sediment subduction and tectonic/ subduction erosion [Stern, Scholl, 2010].

The major site of fossil IOAs in Asia, except for the modern western Pacific, is the Central Asian Orogenic Belt (CAOB), the world's largest accretionary orogenic belt. According to numerous geological, geochemical and isotopic data obtained during the last 15 years the CAOB was a major site of juvenile crustal growth during the Phanerozoic (e.g. [Jahn et al., 2000; Kovalenko et al., 2004; Safonova, 2017]). However, it includes not only oceanic, intra-oceanic and continental margin arc terranes, but also numerous fragments of Precambrian microcontinents and collisional and post- 


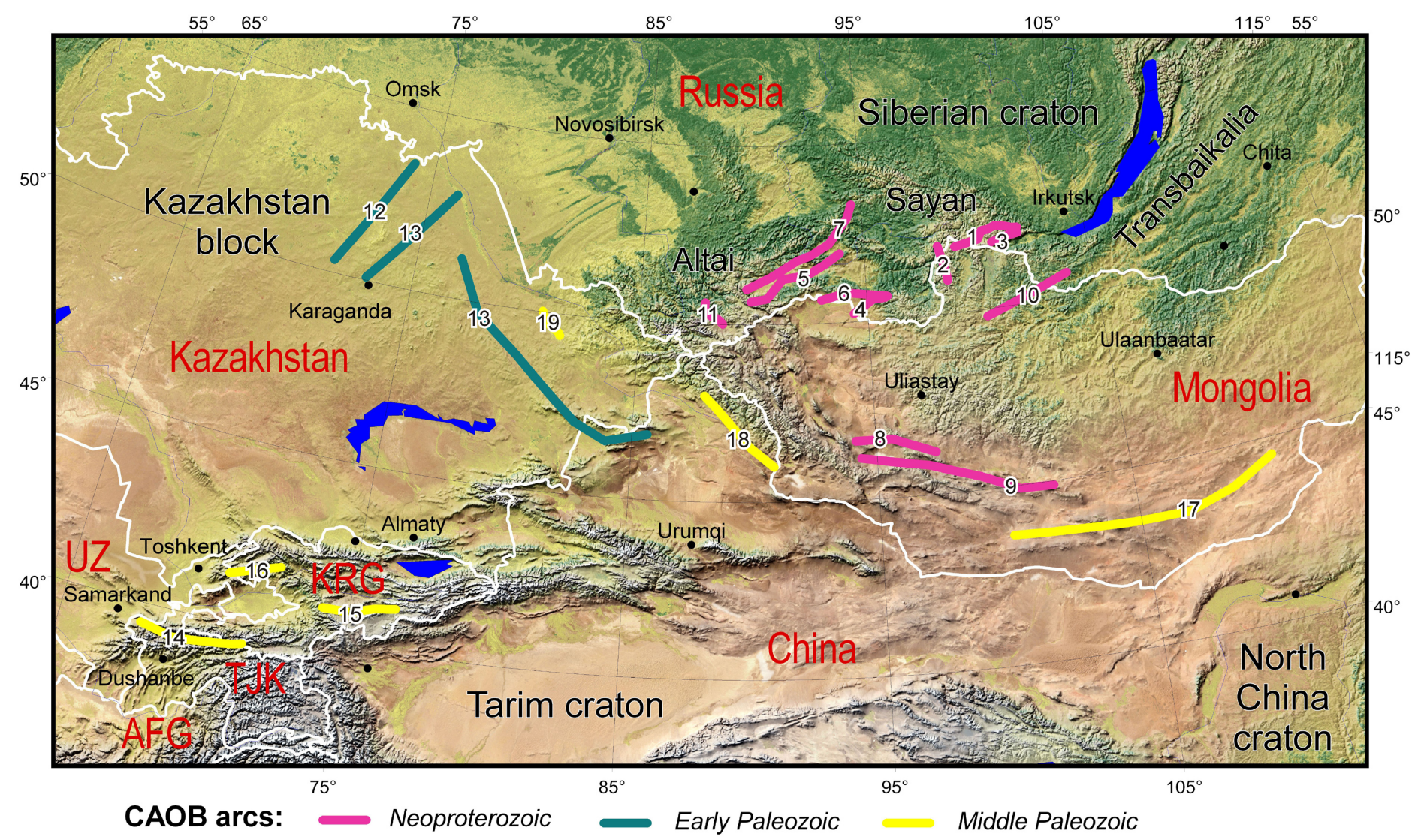

Fossil IOA systems of the CAOB. Siberian Group: Neoproterozoic to early Cambrian IOAs of Siberia and Mongolia (pink). Kazakhstan Group: early Paleozoic arcs of Kazakhstan (blue). Southern Group: middle Paleozoic arcs of the Tienshan, Chinese Altai and Mongolia (yellow). The lengths of arcs were determined with help of ArcView software. AFG, Afghanistan; KRG, Kyrgyzstan; TJK, Tajikistan; UZ, Uzbekistan

collisional complexes. Therefore, identification of intraoceanic arcs within fossil, currently intra-continental orogenic belts is of primary importance.

The IOAs of the CAOB formed in the Paleo-Asian ocean during a period from the late Neoproterozoic to the late Paleozoic. Their fragments have been preserved in the central, western and southwestern segments of the CAOB, in almost all major orogens or foldbelts of the CAOB. Twenty one (or less if considering some as parts of one arc) intra-oceanic arcs have been identified in the Central Asian Orogenic Belt. They formed during three time intervals in the evolution of the Paleo-Asian ocean: Neoproterozoic, Early Paleozoic and Middle Paleozoic. According to their age and geographic position, we divided them into three groups: Siberian, Kazakhstan and Southern [Safonova et al., 2017].

The Neoproterozoic - earliest Cambrian IOAs (Siberian Group) formed in the northern Paleo-Asian ocean, during the early stages of its evolution. The arcs of the Siberian Group now are incorporated into accretionary complexes and adjacent active margin/island-arc terranes of eastern and western Tuva-Sayan regions, Transbaikalia, northern and southwestern Mongolia and Russian Altai. There are eleven fragments of Neoproterozoic to earliest Cambrian arcs, most of which with boninites, with a total length of ca. $2700 \mathrm{~km}$. The oldest IOA system of the Paleo-Asian ocean is represented by the Dunzhugur and Shishkid arcs in the Eastern Tuva-Sayan, which formed at ca. $800 \mathrm{Ma}$, i.e. at earliest stages of Paleo-Asian ocean evolution. The Agardag and Shatskii arcs (and probably the Kurtushibin arc, the precise age of which has not been constrained yet) of the western Tuva-Sayan formed at ca. 580-570 Ma. They evolved almost coevally with the Dariv and Khan-Taishirin arcs of south-western Mongolia and Kurai-Ulagan arc of the Russian Altai. The Tannu-Ola ophiolite represents the youngest arc of the Siberian Group (539-518 Ma). Most of the arcs of this group include both boninites and back-arc deposits and therefore are parts of former intra-oceanic arc systems.

The Kazakhstan Group includes a limited number of intra-oceanic island arcs, which formed and evolved from the Middle Cambrian to the Early Ordovician) and contain few boninites. The Selety-Urumbai (middle to late Cambrian) and Bozshakol-Chingiz (Late Cambrian - Early Ordovician) island-arc terranes are parts of the 
Kazakh orocline. Their intra-oceanic arc origin is not as obvious as that of the Siberian Group, however, there are back-arc formations and abundant tholeiitic volcanic rocks with positive $\mathrm{Nd}$ and $\mathrm{Hf}$ isotope characteristics. The longest arc of the Kazakhstan Group (Middle Cambrian - Ordovician) is the BozshakolChingiz terrane also probably representing a single arc together with the Selety-Urumbai. However, it remains unclear if the Bozshakol-Chingiz arc was a true intraoceanic arc and if it was extended over the whole length of the former subduction zone. The Southern Group is more diverse, both geographically and lithologically and can be split into the Tienshan, East Kazakhstan - West Junggar and South Mongolian subgroups. It includes six Late Ordovician to Devonian arcs, some also with boninites. The Middle Paleozoic arcs formed in the Turkestan/South Tienshan, Junggar/Ob'-Zaisan and South Mongolian oceans, southern branches of the PAO. No boninitic rocks have been identified in the Tienshan arcs of Fan-Karategin and Chatkal-Atbashi. Therefore, their intra-oceanic origin remains debatable. However there are back-arc units and island-arc volcanic rocks with positive $\mathrm{Nd}$ and $\mathrm{Hf}$ isotopic values, and also the island-arc units are associated with back-arc basins. These regions remain understudied though and more reliable identification of intra-oceanic island arcs requires future careful research.

Few, if any, well-defined IOAs of Late Paleozoic age have been recognized in the CAOB. The only Bogda arc in the northern Chinese Tienshan hosts granitoids with positive epsilon $\mathrm{Nd}$ characteristics while its volcanic rocks remain understudied. The eastern CAOB hosts several volcanic belts which may include fragments of IOAs, however, only the Bogdo arc has been reliably recognized so far. The Late Paleozoic was the time of PAO shrinking and suturing and therefore, the ocean was not large enough to produce intra-oceanic arc systems.

The lithologies of the modern and fossil arcs are similar, although geochemically the fossil arcs contain more calc-alkaline varieties suggesting either their more evolved character, which agrees well with their recorded longer life span or there were different conditions of magma generation. In addition, an intraoceanic arc may represent an early stage in the evolution of immature arcs and accordingly they are longer living. The boninites of fossil IOAs of the Paleo-Asian ocean have essentially identical whole-rock geochemistry (apart from potassium) to the modern fresh boninites of the Tonga Trench, whereas the tholeiitic and calcalkaline volcanic rocks show much wider variations of major oxides.

Of special importance is the identification of backarc basins in old accretionary orogens, because boninites, which are often considered as a key diagnostic feature of IOA, may be absent in both modern and fossil IOAs. The formation of back-arc basins might have followed three scenarios: active margin rifting, intraoceanic arc rifting and fore-arc rifting [Stern, 2010]. The active margin rifting forms an initial IOA and an initial back-arc basin parallel to a still active continental arc. The volcanic front without interruption shifts oceanward and forms an intra-oceanic arc. The Sea of Japan possibly formed by a similar scenario, when the Japanese Islands were rifted off the East Asia active continental margin in Early Miocene time, i.e. at ca. 20-15 Ma. A similar situation can be reconstructed in the Middle Cambrian - Early Ordovician island-arc terranes of the Kazakh orocline [Safonova et al., 2017]. The intra-oceanic arc rifting forms a new arc parallel to still active initial arc and a new back-arc basin leaving a remnant basin in the rear part of the subduction system. The rifted part of the arc is split from the volcanic front to form a remnant arc that subsides as the spreading continues. Such a scenario probably acted in the Mariana IOA system and in the Devonian Gurvansayhan-Zoolen IOA of southern Mongolia. The fore-arc rifting also forms a new arc whereas the active arc migrates continentward and, with time, becomes a remnant arc. The Shishkhid IOA of eastern Tuva-Sayan probably formed by such a scenario.

The major parameters of IOA are geometric length, life length and dominating lithologies with related geochemical signatures. The total length of IOAs in the Circum-Pacific is more than $20000 \mathrm{~km}$. The longest is the Mariana - Izu-Bonin IOA system, which extends for a distance of about $4000 \mathrm{~km}$, spanning about 50 m.y., from the Eocene to the present time. The total length of the arcs of the Siberian Group is around $2700 \mathrm{~km}$. The longest arcs, or the longest preserved segments of the fossil arcs, are the Kurtushibin and Khan-Taishirin island-arc terranes, 440 and $610 \mathrm{~km}$, respectively. The total length of middle Cambrian to Ordovician arcs (Kazakh Group) is about $1500 \mathrm{~km}$. The lengths of the IOAs of the Souther Group is about $2000 \mathrm{~km}$ long; the longest arc of this group is the Gurvansayhan-Zoolen island-arc terrane of southern Mongolia, which extends for a distance of more than $850 \mathrm{~km}$.

A very important issue is subduction erosion and post-orogenic tectonics both could partly or fully destroy the intra-oceanic arc complexes [Scholl, von Huene, 2007; Yamamoto et al., 2009; Safonova et al., 2015]. In addition, may direct subduction into the deep mantle. For example, there are at least six intra-oceanic arcs in the Philippine Sea, the largest of which are the Kyshyu-Palau and Izu-Bonin arcs, which, according to P-wave tomographic data, are currently subducting under the Honshu arc down to the mantle with minor to nil accretion instead, thus suggesting ongoing tectonic erosion and/or delamination of arc crust. This may result in partial or complete disappearance of 
IOAs. Therefore, the structural and compositional records of fossil IOAs of the CAOB allow us to make minimal estimations of their geometric length, life length, crust thickness and dominant lithologies. Consequently, while identifying the nature of a suprasubduction terrane, we should take into account the whole integrity of available data: the absence/presence of boninites, the absence/presence of back-arc basin assemblages, the tholeiitic versus calc-alkaline domi- nant lithology, whole-rock Nd and Hf-in-zircon isotopes, etc.

Acknowledgements. The study was supported by the Ministry of Education and Science of the Russian Federation (project no. 14.Y26.31.0018). Additional support came from the Scientific Projects of IGM SB RAS, Labs 211 (no. 0330-2016-0003) and 284 (no. 0330-2016-0018), and from the Russian Foundation for Basic Research (grant \# 16-05-00313).

\section{REFERENCES}

Clift P.D., Schouten H., Draut A.E., 2003. A general model of arc-continent collision and subduction polarity reversal from Taiwan and the Irysh Caledonides. In: R.D. Larter, P.T. Leat (Eds.), Intraoceanic subduction systems (Tectonic and Magmatic Processes). Geological Society, London, Special Publications, vol. 219, p. 81-98. https://doi.org/ 10.1144/GSL.SP.2003.219.01.04.

Jahn B., Wu F., Chen B., 2000. Granitoids of the Central Asian Orogenic Belt and continental growth in the Phanerozoic. Transactions of the Royal Society of Edinburgh: Earth Sciences 91 (1-2), 181-193. https://doi.org/10.1017/S0263 593300007367.

Kovalenko V.I., Yarmolyuk V.V., Kovach V.P., Kotov A.B., Kozakov I.K., Salnikova E.B., Larin A.M., 2004. Isotope provinces, mechanisms of generation and sources of the continental crust in the Central Asian mobile belt: geological and isotopic evidence. Journal of Asian Earth Science 23 (5), 605-627. https://doi.org/10.1016/S1367-9120(03)00130-5.

Maruyama S., Omori S., Sensu H., Kawai K., Windley B.F., 2011. Pacific-type orogens: new concepts and variations in space and time from present to past. Journal of Geography 120, 115-223 (in Japanese with English abstract and captions).

Safonova I.Y., 2017. Juvenile versus recycled crust in the Central Asian Orogenic Belt: implications from ocean plate stratigraphy, blueschist belts and intraoceanic arcs. Gondwana Research 47, 6-27. https://doi.org/10.1016/j.gr. 2016.09.003.

Safonova I., Kotlyarov A., Krivonogov S., Xiao W., 2017. Intra-oceanic arcs of the Paleo-Asian ocean. Gondwana Research (in press). https://doi.org/10.1016/j.gr.2017.04.005.

Safonova I., Maruyama S., Litasov K., 2015. Generation of hydrous-carbonate plumes in the mantle transition zone linked to tectonic erosion and subduction. Tectonophysics 662, 454-471. https://doi.org/10.1016/j.tecto.2015. 08.005 .

Scholl D.W., von Huene R., 2007. Crustal recycling at modern subduction zones applied to the past - issues of growth and preservation of continental basement crust, mantle geochemistry, and supercontinent reconstruction. In: R.D. Hatcher, Jr., M.P. Carlson, J.H. McBride, J.R. Martínez Catalán (Eds.), 4-D framework of continental crust. Geological Society of America Memoirs, vol. 200, p. 9-32. https://dx.doi.org/10.1130/2007.1200(02).

Stern R., 2010. The anatomy and ontogeny of modern intra-oceanic arc systems. In: T.M. Kusky, M.-G. Zhai, W. Xiao (Eds.), The evolving continents: Understanding processes of continental growth. Geological Society, London, Special Publications, vol. 338, p. 7-34. https://doi.org/10.1144/SP338.2.

Stern R.J., Scholl D.W., 2010. Yin and Yang of continental crust creation and destruction by plate tectonics. International Geology Review 52 (1), 1-31. https://doi.org/10.1080/00206810903332322.

Yamamoto S., Senshu H., Rino S., Omori S., Maruyama S., 2009. Granite subduction: arc subduction, tectonic erosion and sediment subduction. Gondwana Research 15 (3-4), 443-453. https://doi.org/10.1016/j.gr.2008.12.009. 